\title{
Possibilities of using preservatives in environmentally friendly furniture industry
}

\author{
Abdi ATILGAN ${ }^{1}$, Hüseyin TAN ${ }^{2}$, Dursun Kemal BAYRAKTAR ${ }^{2}$ and Hüseyin PEKER $^{1 *}$ \\ ${ }^{1}$ Faculty of Forestry, Artvin Çoruh University, Artvin, Turkey. \\ ${ }^{2}$ Faculty of Forestry, Karadeniz Teknik Üniversitesi, Trabzon, Turkey.
}

Accepted 7 June, 2012

\begin{abstract}
Impregnation of the wooden equipment used as furniture, decoration and building materials, outdoor effects and some kinds of air situations as a result of varnishing is studied in this work. Especially, the changes in the wooden material, varnish and impregnation material, used massively in furniture are studied according to seasons (spring, summer, autumn, winter) and months (3, 6, 9 and 12). According to the results, the highest retention in Scotch pine wood occurred in water repellent + polyurethane varnish $\left(82.02 \mathrm{~kg} / \mathrm{m}^{3}\right)$ and in chestnut tree wood occurred in water repellent + polyurethane varnish $\left(9.80 \mathrm{~kg} / \mathrm{m}^{3}\right)$. The highest brightness level is measured in the 9th month $(52.56 \%)$ for Scotch pine and in the 12th month (67.94\%) for chestnut tree. The highest percentage of colour change is measured in 4th season $(67.07 \%)$ for Scotch pine and also in 4th season $(55.95 \%)$ for chestnuts tree. The highest percentage of adherence resistance is measured in the 9th month $(3.83 \%)$ for Scotch pine and in the 3, 6 and 9th months (3.66\%) for chestnut. The highest rate of weight loss is measured as $0.99 \mathrm{~g}$ in Scotch pine while it is $0.66 \mathrm{~g}$ in chestnut tree.
\end{abstract}

Key words: Impregnation, wood, varnishes, weathering, color changes, gloss.

\section{INTRODUCTION}

Furniture is a "fashionable product" that changes constantly according to technical and economic conditions of our time. Designing models for customers in the aspect of aesthetics, endurance and functionality is very important for the production of furniture. Wood is used as raw material. Wooden plaques like scale and filamentous tables are highly preferred in the production of box shaped modular furniture (Altınok, 1987). Wood that can be used when it is solid or when it turns into composed products is one of the unique materials that is suitable for physical, mechanical, chemical or biochemical interference (Bozkurt and Göker, 1986). It also needs protection according to humidity of the place where it is used, its $\mathrm{pH}$ level, temperature and presence of dangerous micro organisms (Bozkurt et al., 1993). It should be impregnated by chemical substances in order to prevent damages that may happen to the wood

\footnotetext{
${ }^{\star}$ Corresponding author. E-mail: peker100@hotmail.com. Tel: +90-462-3773623. Fax: +90-466-2151035.
}

(Yalınkılıç, 1993). Air conditions are the most dangerous things to the wood. Temperature, humidity, different wave lengths and severe gun light and their changes in the different times of the day according to seasons create negative effects on the furniture (Williams and Feist, 1993; Özen and Sönmez, 1996). It is proved that varnish only or impregnation has aesthetics and protective effects on furniture and as well as increasing their life span (Feist, 1990; Özen and Gözeneli, 1992). Williams and Feist (1991) at first exposed the wooden surfaces to the outside effects and then tried to determine the performance of varnish layers by exposing them to the outside effect after varnishing. Grantham and Black (1976) observed the different characteristics of varnish layers and wood protectors that are exposed to the external effects, having penetration ability. Wood has been regarded as having an engineering attraction with its natural structure, endurance and structural abilities.

On the contrary, wood is an enduring material and harmonious with the environment. It was used widely in the tombs of kings, and became fashionable in the 20th century (Feist, 1988). Impregnated wood has a wide use 


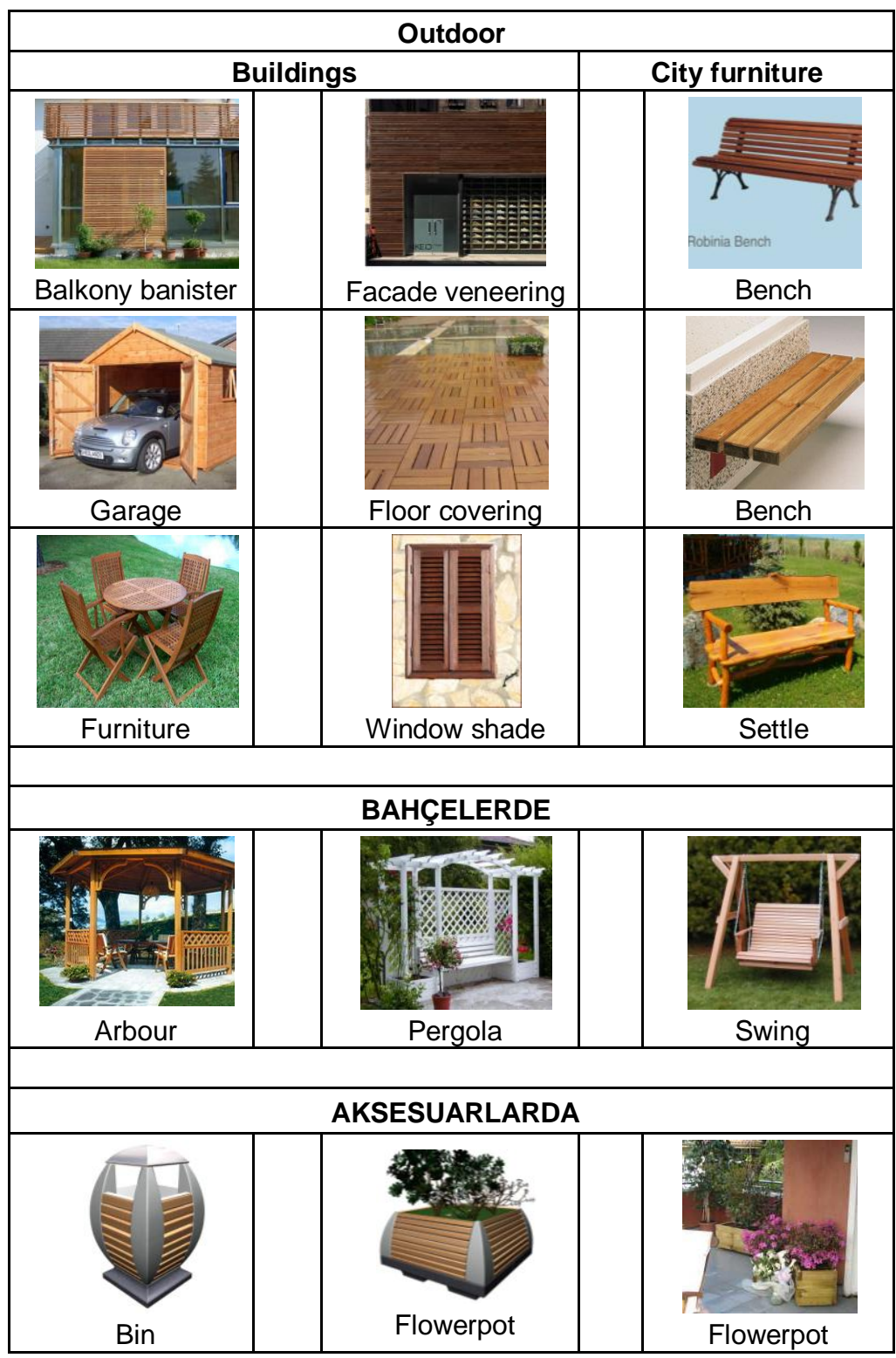

Figure 1. The places impregnation wood is used exterior.

area, both indoor and out door. Outdoor areas include kinder gardens, verandas, arbores, gazeboes, pagoda plate, stairs, garage, bridges, rubbish cans, ground material (around the pool) (Boxall and Hayes, 1984) (Figure 1). Indoor: it is used in vertical circulation places (wooden stairs), furniture (balcony chair or table), winter gardens, door, wooden flower beds and wet places (bathroom floor, bathtub, sauna) (Figure 2). The aim of this paper is to study the use of furniture and construction industry impregnated with varnish. The wood species were investigated by supporting the usability performance. By using the connection of wood-varnishimpregnation, its endurance against external and internal effects is researched.

\section{MATERIALS AND METHODS}

In the scope of the study, Scotch pine (Pinus sylvestris L.) and Anatolian chestnut tree (Castenaea sativa Mill.) wood were used. Tanalith-CBC (13\%)-white spirit- celluloses thinner and polyurethane varnish are preferred because of the indoor and outdoor conditions.

\section{Supplying and preparing the experiment materials}

Tree types belong to East Black Sea Region (Table 1) panels that are chosen by samples method and whose yearly circles are roughly cut as $190 \times 140 \times 15 \mathrm{~mm}$; they are acclimatized until their weight becomes stable in $20 \pm 2^{\circ} \mathrm{C}$ and $60 \pm 5 \%$ humidity. Then, it is 


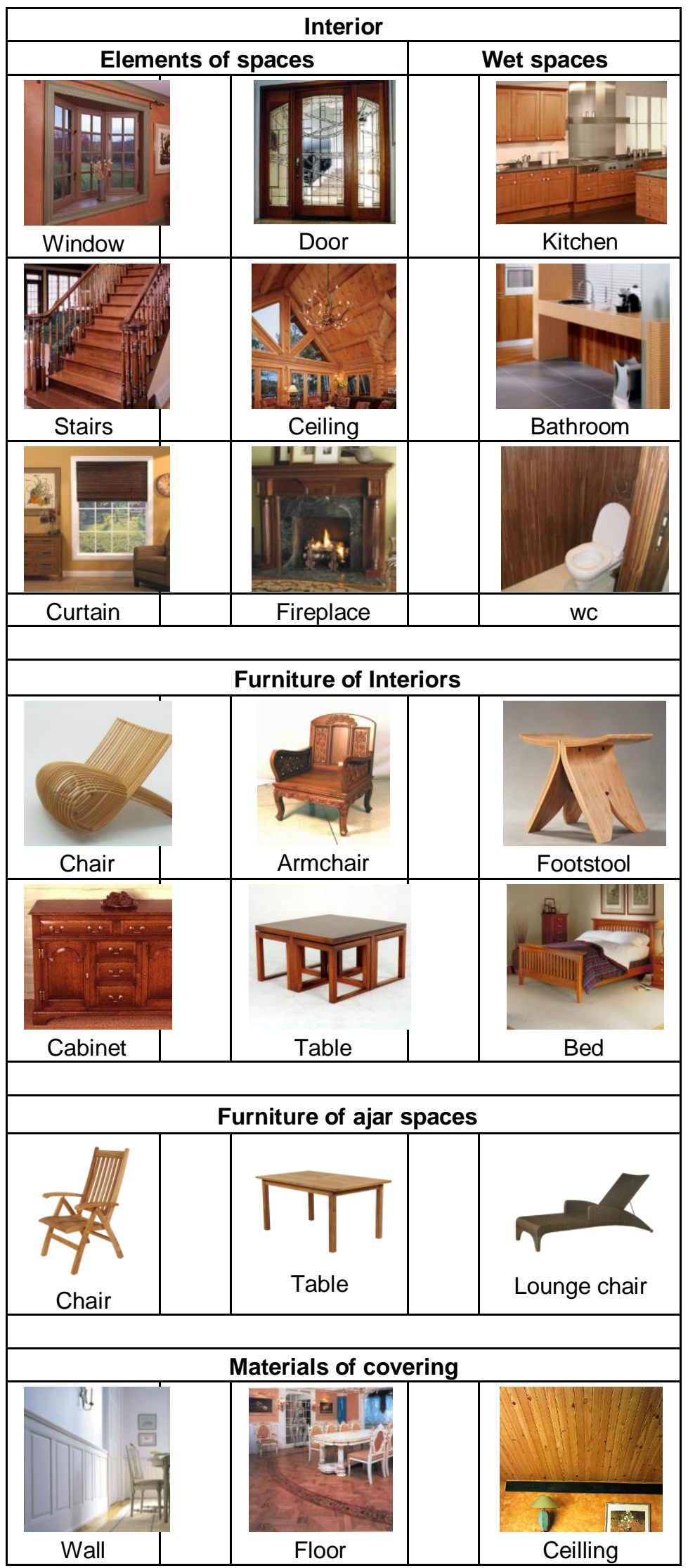

Figure 2. The places impregnation wood is used interior. 
Table 1. Cutting areas of wood specify.

\begin{tabular}{cllccc}
\hline Wood number & Forest working & Wood specify & Length $(\mathbf{m})$ & Chest bore (cm) & High $(\mathbf{m})$ \\
\hline 1 & Çaykara & Pinus & 25.00 & 40 & 1700 \\
2 & Pazar & Castanea & 30.00 & 35 & 1400 \\
\hline
\end{tabular}

set to original panel measure, which is $150 \times 100 \times 10 \mathrm{~mm}$ and ready for varnishing. Control and experiment samples are in the same humidity level. For every variation, one test and one control sample is taken and prepared for the impregnation after being recorded according to season of tree and varnish type (ASTM 358, 1978; TS 4755, 1986; Baysal, 1994; Var, 1994).

\section{Preparation of impregnation solutions}

Solutions that are used in the impregnation of experiment samples are chosen according to literature, and A total of three impregnation mixtures (two water repellent and variation pure mixture) are used. In these mixtures, light organic solutions (toluene, thinner, benzyl, white spirit) are used especially.

- Tanalith-CBC is decomposed in pure water and mixed up in room temperature $(1.13 \%)$.

- Paraffin $(2.1 \%)$

- White spirit (79\%).

- Varnish (synthetic varnish) (20\%).

- Paraffin (3.1\%).

- Celluloses thinner (79\%).

- Varnish (polyurethane varnish) (20\%).

The temperature of the prepared solutions is measured before and after the impregnation. $\mathrm{pH}$ and thickness of it is also measured before and after impregnation.

\section{Impregnation method}

In impregnation process, samples are kept in a solution vulnerable to air pressure for 60 min after applying vacuum equal to $60 \mathrm{~cm} / \mathrm{Hg}$ for $60 \mathrm{~min}$ according to the basis stated in ASTM D- 1413-76 (1988). After recording the weight of every sample, they are kept in kiln dry places until they reach $105^{\circ} \mathrm{C}$ and weighted again in a sensitivity of $0.01 \mathrm{~g}$. After impregnation, every impregnated sample is kept in a place where air circulation happens for 10 to 15 days for evaporation of the solutions.

1. Retention absorbed material quantity $\left(\mathrm{kg} / \mathrm{m}^{3}\right)$

$\mathrm{R}_{1}=\mathrm{G}_{1} \times \mathrm{C} \times 10\left(\mathrm{~kg} / \mathrm{m}^{3}\right)$

$\mathrm{G}_{1}=\mathrm{T} 2-\mathrm{T} 1$

$\mathrm{T}_{1}=$ Sample weight before impregnation $(\mathrm{g})$

$\mathrm{T} 2=$ Sample weight after impregnation $(\mathrm{g})$

$\mathrm{V}=$ Capacity of sample $\left(\mathrm{cm}^{3}\right)$

$\mathrm{C}=$ Concentration $(\%)$

2. Retention (In comparison with completely dry wood) quantity of dry material (\%)

$\mathrm{R}_{2}=$ Moes-Moeox10 (\%)

Moeö=Weight of the exactly dry wood before impregnation $(\mathrm{g})$

Moes=Weight of the exactly dry wood after impregnation (g)

(Richardson, 1978)

Preparation of varnishes and varnishing the experiment sample

Varnishing the experiment samples is done according to industrial application and ASTM D-3023 (ASTM D 3023, 1988) by using viscometer in the measurements of Dyn/4 mm. In polyurethane varnish, $18 \mathrm{sn} /$ dyn Cup $-4 \mathrm{~mm} / 20^{\circ} \mathrm{C}$, in synthetic varnish $18 \mathrm{sn} / \mathrm{dyn}$ Cup $-4 \mathrm{~mm} / 20^{\circ} \mathrm{C}$ is determined.

Polyurethane varnish - Material used for filling: $100 \mathrm{~g} / \mathrm{m}^{2}$

Upper layer: $100 \mathrm{~g} / \mathrm{m}^{2}$

Synthetic varnish: Material used for filling:

Colourless: Transparent

Upper layer: $100 \mathrm{~g} / \mathrm{m}^{2}$ (3 layers)

Varnishing process is done according to the basis of varnishing the two sides of the panel equally. Experiment and control samples are put in experiment stand in a position such that their surface is turned to the South at $45^{\circ}$.

\section{Determining the solid material and dry band thickness in varnishes}

Sooth and transparent watch glass whose thickness is $4 \mathrm{~mm}$ is cut at the size of $100 \times 100 \mathrm{~mm}^{2}$. Its surface is cleaned with natural alcohol and then dried; its tare is determined with a scale that has a sensitivity of $0.01 \mathrm{~g}$. After determining solid material, varnish is mixed in its package and then $1 \mathrm{~g}$ is taken and weighted. The agent of solid material is found to be $52 \%$ in synthetic varnish and $40 \%$ in polyurethane varnish. When the experiment device is on the smooth glass or sheet iron in a vertical position, indicator is placed on zero and the thickness of dry band is determined.

\section{Methods used in the tests of experiment samples}

\section{Measuring the solidity}

The solidity of the samples that are varnished and prepared for experiment is measured with pendulum solidity measurement device. While the device is placed on platform, layer solidities are determined according to pendulum oscillations waving with two marbles whose strength are $63 \pm 3.3 \mathrm{HRC}$ and diaper is $5 \pm 0.005$. Two pendulums are used in the measurement of solidity and oscillation; the beginning and ending points vary according to the type of pendulum. Oscillations from $12^{\circ}$ to $4^{\circ}$ for Pezos and from $6^{\circ}$ to $3^{\circ}$ for Koning are measured. After varnishes that are applied to the surfaces of samples are dried completely by acclimatizing them for $16 \mathrm{~h}$ in $23 \pm 2^{\circ} \mathrm{C}$ and in the humidity of $50 \pm 5 \%$, they are made ready for experiment (ASTM 4366, 1980; Özen and Gözeneli 1992).

\section{Measuring the brightness}

Brightness is measured with brightness measuring device (Glossmetre). After completely drying and determining the thickness at the samples bands, they are prepared for experiments by acclimatizing them at $23 \pm 2^{\circ} \mathrm{C}$ and in an environment that has $50 \pm 24^{\circ}$ humidity for16 h. Brightness measuring device is used in $60 \pm 2^{\circ}$ while measuring is calibrated during and before any process. For daily calibration, black glass that is well varnished, with smooth surface 
Table 2. Features of solutions.

\begin{tabular}{llccccc}
\hline Treatment chemicals & Thinner & Warmth $\left({ }^{\circ} \mathbf{C}\right)$ & & PH & \multicolumn{2}{c}{ Density $(\mathbf{g} / \mathbf{m l})$} \\
\hline Varnishes & & & TB & TA & TB & TA \\
Untreatment & - & - & - & - & - & - \\
Tanaltth - CBC & Pure water & 23 & 3.05 & 3.05 & 1.08 & 1.08 \\
WR+ Senthetic thinner & W. spirit & 100 & 5.57 & 5.57 & 0.820 & 0.821 \\
WR+ Cellulosicthinner & Cellulosic & 100 & 5.06 & 5.06 & 0.880 & 0.880 \\
Senthetic varnish & W. spirit & 23 & 6.0 & 6.01 & 0.940 & 0.940 \\
Polyürethane varnish & Cellulosic & 23 & 6.0 & 6.66 & 1.010 & 1.010 \\
\hline
\end{tabular}

WR, Water repellent; TB, treatment before; TA, treatment after.

whose reflection index is 1.567 and brightness determined to 100 for any geometric shape is used (ASTM 2244, 1990)

\section{Colour change}

Colour measurements are made with colour measuring devices according to ASTM D-2244 and white colour whose measuring device is calibrated as $a=4.91 ; b=3.45 ; c=6.00 ; \quad H=324.9$. First, measurement happens when it is natural (in natural colour); second, one happens before the experiment when it is varnished and other measurements happen in different time periods. Experiment panels are cleaned one by one before the experiments (ASTM 2244, 1990).

\section{Resistance of adherence to the surface}

Adherence resistance to the surface of varnish layers that are applied to the wooden surfaces is determined after cutting the varnish layers in certain periods by pulling a band over the surface. The incisory used in the experiment is made of a special angel steel; and angle of its sharp side is 15 to $30^{\circ}$ for the layers whose dry thickness is up to 50 micron. 11 sharp side and $1 \mathrm{~mm}$ spaced incensories are used. Four layers whose dry layer thickness is between 50 and 125 micron, with $2 \mathrm{~mm}$ space and 6 sharp side incensories are used; and for the ones that are thicker than 120 micron razor blade, lancet and cutting like these are used (ASTM 3359,1976; TS 6884,1989).

\section{Measuring the loss of weight}

Weight of experiment samples that are impregnated and varnished is recorded before the outdoor effect and after outdoor effect with $0.01 \mathrm{gr}$ sensibility along with control sample. Control and test sample are weighed one by one after keeping them in climatic conditions especially before the outdoor effect. Losses are measured as (gr) in varnished impregnation varnish and natural samples (ASTM 661, 1993; ASTM, 1972; Garlack and Sward, 1972).

\section{Using statistical methods}

All the date obtained in experiments are utilized with the help of a computer programme called "STATGRAF", simple variance analyses, various variance analyses, and connection with data is observed with "Duncan test". Moreover, regression analysis is made to understand the connection between the relative humidity and temperature levels.

\section{FINDINGS}

\section{Findings related to features of impregnation solutions}

Findings related to the features of solutions are given in Table 2 thus:

1. There has been no change in the rates of $\mathrm{pH}$ and density of solutions that are measured before and after impregnation.

2. The fact is the rate of $\mathrm{pH}$ in the Tanalith-CBC $13 \%$ solution is acidic and the negative effects of these solutions on the polysaccharides present in the wood increases the possibility of hydrolysis.

3. The fact is $\mathrm{pH}$ rates of the solutions used are close to neutral, showing that chemical substances in the wood are affected very low. Mixtures in impregnation process are used as individual processes.

\section{Findings related to Scotch pine's and chestnut trees' retention rate}

Findings about retention rate are given in Table 3 thus:

1. The highest retention happens in water repellent + polyurethane varnish $\left(82.02 \mathrm{~kg} / \mathrm{m}^{3}\right)$ for Scotch pine wood, while the lowest rate happens in water repellent + polyurethane varnish.

2. The highest rate materializes in water repellent + polyurethane varnish $\left(9.80 \mathrm{~kg} / \mathrm{m}^{3}\right)$ for Scotch pine tree while the lowest rate belongs to Tanalith-CBC (5.33 $\mathrm{kg} / \mathrm{m}^{3)}$.

\section{Findings related to the percentage of retention in Scotch pine and chestnut}

Findings related to the percentage of retention are given in Table 4. The highest percentage of retention for Scotch pine materializes in water repellent + synthetic varnish $(42.33 \%)$; while for chestnut tree, it is water repellent + polyurethane varnish $(9.22 \%)$ that has the highest percentage of retention. 
Table 3. Retention rates $\left(\mathrm{kg} / \mathrm{m}^{3}\right)$.

\begin{tabular}{llccc}
\hline \multirow{2}{*}{ Wood specify } & \multirow{2}{*}{ Treatment chemicals } & \multicolumn{3}{c}{ Retention $\left(\mathbf{K g} / \mathbf{m}^{3}\right)$} \\
\cline { 3 - 5 } Scoth pine & WR+Senthetic varnishes & 56.13 & $\mathbf{S D}$ & $\mathbf{H g}$ \\
& WR+Polyürethane & 82.02 & 7.00 & $\mathrm{~b}$ \\
& Tanalıth-CBC & 77.55 & 2.31 & $\mathrm{a}$ \\
& & & 2.00 & $\mathrm{a}$ \\
\multirow{3}{*}{ Chestnut } & WR+Senthetic varnish & 9.26 & 1.03 & $\mathrm{c}$ \\
& WR+Polyürethane varnish & 9.80 & 1.91 & $\mathrm{c}$ \\
& Tanalıth-CBC & 5.33 & 0.29 & $\mathrm{~d}$ \\
\hline
\end{tabular}

$\mathrm{AV}$, Average; SD, standard deviation; $\mathrm{Hg}$, homogeneity groups.

Table 4. Retention rates (\%).

\begin{tabular}{lllll}
\hline \multirow{2}{*}{ Wood pecify } & \multirow{2}{*}{ Treatment chemicals } & \multicolumn{3}{c}{ Retention $\left(\mathrm{Kg} / \mathbf{m}^{\mathbf{3}}\right)$} \\
\cline { 3 - 5 } Scoth pine & WV & SD & $\mathbf{H g}$ \\
& WR+Senthetic varnishes & 42.23 & 10.64 & $\mathrm{a}$ \\
& WR+Polyürethane & 24.74 & 1.54 & $\mathrm{~b}$ \\
& Tanalıth-CBC & 42.20 & 12.50 & $\mathrm{a}$ \\
\multirow{3}{*}{ Chestnut } & WR+Senthetic varnish & & & \\
& WR+Polyürethane varnish & 2.95 & 0.79 & $\mathrm{C}$ \\
& Tanalıth-CBC & 9.22 & 6.38 & $\mathrm{C}$ \\
\hline
\end{tabular}

AV, Average; SD, standard deviation; Hg, homogeneity groups.

Table 5. Various variance analyze (testing of duncan) on strength.

\begin{tabular}{|c|c|c|c|c|c|c|c|c|c|}
\hline \multirow{2}{*}{$\begin{array}{c}\text { Seasons/ } \\
\text { Months }\end{array}$} & \multicolumn{2}{|c|}{ Scoth pine } & \multicolumn{2}{|c|}{ Chestnut } & \multirow{2}{*}{$\begin{array}{c}\text { Chemicals } \\
\text { Material }\end{array}$} & \multicolumn{2}{|c|}{ Scoth pine } & \multicolumn{2}{|c|}{ Chestnut } \\
\hline & AV & $\mathrm{Hg}$ & AV & $\mathrm{Hg}$ & & $\mathrm{AV}$ & $\mathrm{Hg}$ & AV & $\mathrm{Hg}$ \\
\hline IS & 48.83 & $\mathrm{~cd}$ & 49.28 & c & 1-Naturel & 18.88 & $d$ & 19.77 & e \\
\hline II S & 43.23 & $d$ & 50.11 & c & 2-S.V. & 37.95 & $c$ & 37.66 & $d$ \\
\hline III S & 61.48 & $a b$ & 58.63 & $a b$ & 3-P.V. & 80.03 & $\mathrm{a}$ & 81.04 & $a$ \\
\hline IV S & 53.16 & $\mathrm{bc}$ & 56.62 & $a b$ & 4-WR+S.V. & 34.98 & c & 38.31 & $d$ \\
\hline $3 M$ & 41.56 & $d$ & 61.94 & $a$ & 5-WR+P.V. & 53.70 & $b$ & 70.92 & $\mathrm{~b}$ \\
\hline $6 \mathrm{M}$ & 58.09 & $a b c$ & 60.83 & a & 6-Tan+SV & 57.85 & $\mathrm{~b}$ & 55.31 & $\mathrm{c}$ \\
\hline $9 M$ & 49.70 & $\mathrm{~cd}$ & 55.23 & $a b$ & 7-Tan+.PV & 85.36 & $\mathrm{a}$ & 85.00 & $a$ \\
\hline $12 \mathrm{M}$ & 65.39 & a & 50.80 & $c$ & - & - & - & - & - \\
\hline
\end{tabular}

S, Seasons; M, months; SV, synthetic varnish; PV, polyurethane varnish.

\section{Findings related to strength rate}

Varnish-impregnation materials based on season and months that affect the strength level and also various similar analyses determining both types are given in Tables 5 and 6.

It is at the 12th month $(65.33 \%)$ that the highest percentage is measured for Scotch pine tree and it is polyurethane varnish that has the highest rate considering the usage of chemical substances. For chestnut tree, it is at the 3rd and 6th months the highest percentage was recorded and it is Tanalith-CBC+ polyurethane varnish $(85 \%)$ that has the highest percentage considering the chemical substances.

\section{Results of brightness level (parallel to fibres)}

Various similar analyses of both types are given in Tables 7 and 8. According to this situation, the highest 
Table 6. Various variance analyze on chestnut and scoth pine.

\begin{tabular}{|c|c|c|c|c|c|}
\hline VB & CT & SD & FD & $\mathbf{F h}$ & ID \\
\hline \multicolumn{6}{|l|}{ Scoth pine } \\
\hline Chemicals treatment & 3536.17 & 7 & 505.16 & 6.091 & 0.0001 \\
\hline Season-month & 28131.79 & 6 & 4688.63 & 56.536 & $0.0000^{*}$ \\
\hline Estimate ratio & 3483.16 & 42 & 82.93 & - & - \\
\hline Total & 35151.13 & 55 & - & - & - \\
\hline \multicolumn{6}{|l|}{ Chestnut } \\
\hline Chemicals treatment & 11959.99 & 7 & 170.85 & 22.12 & 0.0520 \\
\hline Season-month & 29206.77 & 6 & 4867.78 & 63.148 & $0.0000^{*}$ \\
\hline Estimate ratio & 3237.59 & 42 & 77.08 & - & - \\
\hline Total & 33640.31 & 55 & - & - & - \\
\hline \multicolumn{6}{|c|}{ Duncan testing of both types wood specify } \\
\hline Wood specify & 143.51 & 1 & 143.51 & 1.253 & 0.2657 \\
\hline Chemicals treatment & 57179.89 & 6 & 9529.98 & 83.22 & $0.0000^{*}$ \\
\hline Season-month & 2501.08 & 7 & 357.29 & 3.72 & 0.0052 \\
\hline Estimate ratio & 11107.63 & 97 & 114.51 & - & - \\
\hline Total & 70932.12 & 111 & - & - & - \\
\hline
\end{tabular}

VR, Variance base; CT, checked total; SD, freedom degree; ID, Importance degree.

Table 7. Various variance analyze (testing of duncan) on brightness.

\begin{tabular}{lcccclcccc}
\hline Seasons/ & \multicolumn{2}{c}{ Scoth pine } & \multicolumn{2}{c}{ Chestnut } & \multicolumn{2}{c}{ Chemicals } & \multicolumn{2}{c}{ Scoth pine } & \multicolumn{2}{c}{ Chestnut } \\
\cline { 2 - 9 } Months & AV & Hg & AV & Hg & Material & AV & Hg & AV & Hg \\
\hline I M & 40.15 & bc & 43.80 & c & 1-Naturel & 3.41 & c & 2.83 & d \\
II M & 39.25 & bc & 51.16 & bc & 2-S.V. & 39.25 & a & 76.05 & a \\
III M & 41.59 & bc & 47.83 & bc & 3-P.V. & 60.45 & a & 59.71 & bc \\
IVM & 46.86 & ab & 54.10 & b & 4-WR+S.V. & 56.57 & a & 52.36 & c \\
3 Month & 35.27 & c & 54.01 & b & 5-WR+P.V. & 51.31 & a & 69.97 & ab \\
6 Month & 44.75 & abc & 55.69 & b & 6-Tan+SV & 34.77 & b & 69.21 & a \\
9 Month & 52.56 & a & 66.45 & a & 7-Tan+.PV. & 34.95 & b & 57.71 & C \\
12 Month & 44.46 & abc & 67.94 & a & - & - & - & - & - \\
\hline
\end{tabular}

S, Seasons; M, months; SV, synthetic varnish; PV, polyurethane varnish.

percentage related to seasons and months materialized at the end of the 9th month $(69.31 \%)$. The highest rate considering chemical substance materialized in water repellent + polyurethane varnish (68.74\%). Big differences exist in chestnut tree related to seasons and chemical substances. According to this situation, the highest brightness level $(76.19 \%)$ is measured at the end of the 9th month and the highest brightness level related to chemical substances $(80.26 \%)$ materialized when synthetic varnish was used only.

\section{Finding related to the changing colour angle}

Impregnation material, varnished based on seasons and months that affect colour change in addition to similar analyses of both types are given in Tables 9 and 10 .

In Tables 11 and 12, there is no big difference considering seasons and chemical substance for Scotch pine tree. Hence the highest level materialized at the end of the 4th season (67.01\%). No difference has been spotted in chestnut tree according to seasons or chemical substances. It is found in Tanalith - $\mathrm{CBC}+$ polyurethane varnish (58.02).

\section{Findings related to adherence resistance}

Varnish impregnation materials based on season and months that affect the changes of adherence of resistance 
Table 8. Various variance analyze on chestnut and scoth pine.

\begin{tabular}{|c|c|c|c|c|c|}
\hline VB & CT & SD & FD & Fh & ID \\
\hline \multicolumn{6}{|l|}{ Scoth pine } \\
\hline Chemicals treatment & 1367.23 & 7 & 195.31 & 1.968 & 0.0826 \\
\hline Season-month & 20459.21 & 6 & 3409.86 & 34.36 & $0.0000^{*}$ \\
\hline Estimate ratio & 4168.11 & 42 & 99.24 & - & - \\
\hline Total & 25994.56 & 55 & - & - & - \\
\hline \multicolumn{6}{|l|}{ Chestnut } \\
\hline Chemicals treatment & 3445.44 & 7 & 492.20 & 6.959 & $0.0000^{*}$ \\
\hline Season-month & 28569.85 & 6 & 4761.64 & 67.31 & $0.0000^{* *}$ \\
\hline Estimate ratio & 2970.77 & 42 & 70.73 & - & - \\
\hline Total & 34986.06 & 55 & - & - & - \\
\hline \multicolumn{6}{|c|}{ Duncan testing of both types wood specify } \\
\hline Wood specify & 4235.25 & 1 & 4235.25 & 32.02 & $0.0000^{*}$ \\
\hline Chemicals treatment & 44285.21 & 6 & 7380.86 & 55.80 & $0.0000^{* *}$ \\
\hline Season-month & 3511.26 & 7 & 501.60 & 3.79 & 0.0011 \\
\hline Estimate ratio & 12828.62 & 97 & 132.25 & - & - \\
\hline Total & 64860.35 & 111 & - & - & - \\
\hline
\end{tabular}

VR, Variance base; CT, checked total; SD, freedom degree; ID, importance degree.

Table 9. Various variance analyze (testing of duncan) on change of colour angle.

\begin{tabular}{|c|c|c|c|c|c|c|c|c|c|}
\hline \multirow{2}{*}{$\begin{array}{l}\text { Seasons/ } \\
\text { Months }\end{array}$} & \multicolumn{2}{|c|}{ Scoth pine } & \multicolumn{2}{|c|}{ Chestnut } & \multirow{2}{*}{$\begin{array}{l}\text { Chemicals } \\
\text { Material } \\
\end{array}$} & \multicolumn{2}{|c|}{ Scoth pine } & \multicolumn{2}{|c|}{ Chestnut } \\
\hline & AV & $\mathrm{Hg}$ & AV & $\mathrm{Hg}$ & & AV & $\mathrm{Hg}$ & AV & $\mathrm{Hg}$ \\
\hline I M & 63.99 & $a b$ & 54.50 & $a$ & 1-Naturel & 45.37 & C & 48.70 & c \\
\hline II M & 61.97 & $a b$ & 51.71 & $\mathrm{a}$ & 2-S.V. & 56.91 & $b$ & 53.30 & $a b c$ \\
\hline III.M & 62.70 & $a b$ & 53.72 & $a$ & 3-P.V. & 57.09 & $b$ & 55.92 & $a b$ \\
\hline IV.M & 67.01 & $\mathrm{a}$ & 55.95 & a & 4-WR+S.V. & 58.14 & $b$ & 53.09 & $a b c$ \\
\hline 3 Month & 60.21 & $a b$ & 55.08 & $a$ & 5-WR+P.V. & 65.22 & $a b$ & 51.68 & $a b c$ \\
\hline 6 Month & 61.06 & $a b$ & 53.95 & $\mathrm{a}$ & 6-Tan+SV & 75.94 & $\mathrm{a}$ & 55.93 & $a b$ \\
\hline 9 Month & 55.57 & $a b$ & 50.37 & a & 7-Tan+.PV. & 65.63 & $a b$ & 58.02 & a \\
\hline 12 Month & 52.41 & $\mathrm{~b}$ & 55.16 & $\mathrm{a}$ & - & - & - & - & - \\
\hline
\end{tabular}

$\mathrm{S}$, seasons; M, months; SV, synthetic varnish; PV, polyurethane varnish.

and in addition to various analyses of these two types are given in Tables 11 and 12.

There is a difference in Scotch pine tree related to chemical substances while there is no big difference related to season. In Tables 12 and 13, the highest level related to seasons is found at the end of the 9th month (3.83).

\section{Finding related to loss of weight}

Varnish- impregnation materials based on season and months that affect the loss of weight and in addition to various similar analyses of these two types are given in
Tables 13 and 14. There is a big difference in Scotch pine tree considering the seasons and chemical substances.

\section{DISCUSSION}

The most important things in the impregnation of wooden material are not only the processes before it, but also the pressure, temperature applied in its process and periods. These things also cause a decline in the features of the resistance. In terms of strength, only polyurethane varnish or mixture of Tanalith-(BC+ polyurethane varnish) should not be used. In the first process, use Tanalith-(BC 
Table 10. Various variance analyze on chesnut and scoth pine.

\begin{tabular}{lccccc}
\hline VB & CT & SD & FD & Fh & ID \\
\hline Scoth pine & & & & & \\
Chemicals treatment & 1061.90 & 7 & 151.70 & 1.24 & 0.3026 \\
Season-month & 4366.89 & 6 & 727.81 & 5.95 & 0.0001 \\
Estimate ratio & 5133.29 & 42 & 122.22 & - & - \\
Total & 10562.09 & 55 & - & - & - \\
Chestnut & & & & & \\
Chemicals treatment & 173.49 & 7 & 24.78 & 0.63 & 0.7245 \\
Season-month & 464.86 & 6 & 77.47 & 1.98 & 0.0896 \\
Estimate ratio & 1640.07 & 42 & 39.04 & - & - \\
Total & 2270 & 55 & - & - & - \\
& & & & & \\
Duncan testing of both types wood specify & & 1 & 1301.59 & 14.46 & 0.0002 \\
Wood specify & 1301.59 & 6 & 559.47 & 6.21 & $0.0000^{*}$ \\
Chemicals treatment & 3356.84 & 7 & 107.53 & 1.19 & 0.3130 \\
Season-month & 752.75 & 75 & 89.98 & - & - \\
Estimate ratio & 8728.92 & 97 & - & - & - \\
Total & 14140.11 & 111 & & & \\
\hline
\end{tabular}

VR, Varience base; CT, checked total; SD, freedom degree; ID, importance degree.

Table 11. Various variance analyze (testing of duncan) on resistance.

\begin{tabular}{ccccclcccc}
\hline \multirow{2}{*}{$\begin{array}{c}\text { Seasons/ } \\
\text { Months }\end{array}$} & \multicolumn{2}{c}{ Scoth pine } & \multicolumn{2}{c}{ Chestnut } & \multicolumn{2}{c}{ Chemicals } & \multicolumn{2}{c}{ Scoth pine } & \multicolumn{2}{c}{ Chestnut } \\
\cline { 2 - 11 } & $\mathbf{A V}$ & $\mathbf{H g}$ & $\mathbf{A V}$ & $\mathbf{H g}$ & Material & $\mathbf{A V}$ & $\mathbf{H g}$ & $\mathbf{A V}$ & $\mathbf{H g}$ \\
\hline I M & 3.40 & $\mathrm{ab}$ & 3.38 & $\mathrm{a}$ & 1-Naturel & - & - & - & - \\
II M & 3.27 & $\mathrm{~b}$ & 3.52 & $\mathrm{a}$ & 2-S.V. & 4.20 & $\mathrm{c}$ & 4.35 & $\mathrm{a}$ \\
III M & 3.46 & $\mathrm{ab}$ & 3.35 & $\mathrm{a}$ & 3-P.V. & 4.49 & $\mathrm{a}$ & 4.16 & $\mathrm{ab}$ \\
IV M & 3.78 & $\mathrm{ab}$ & 3.66 & $\mathrm{a}$ & 4-WR+S.V. & 4.19 & $\mathrm{ab}$ & 4.02 & $\mathrm{ab}$ \\
3 Month & 3.73 & $\mathrm{ab}$ & 3.66 & $\mathrm{a}$ & 5-WR+P.V. & 4.20 & $\mathrm{ab}$ & 3.95 & $\mathrm{~b}$ \\
6 Month & 3.59 & $\mathrm{ab}$ & 3.66 & $\mathrm{a}$ & 6-Tan+SV & 3.90 & $\mathrm{~b}$ & 4.07 & $\mathrm{ab}$ \\
9 Month & 3.83 & $\mathrm{a}$ & 3.37 & $\mathrm{a}$ & 7-Tan+.PV. & 4.11 & $\mathrm{ab}$ & 4.08 & $\mathrm{ab}$ \\
12 Month & 3.74 & $\mathrm{ab}$ & 3.55 & $\mathrm{a}$ & - & - & - & - & - \\
\hline
\end{tabular}

$\mathrm{S}$, seasons; M, months; SV, synthetic varnish; PV, polyurethane varnish.

impregnation); and as second process, cover with polyurethane varnish. This increased the strength in Scotch pine tree and chestnut tree after outdoor effects. This increase is almost two times as much as the first condition (Williams and Feist, 1991; Feist, 1988; Sönmez, 1989; Rowell et al., 1981).

\section{Brightness}

Erosion on the surface decreases the layer brightness or the brightness increases in a vertical or horizontal way to the fibres according to the impregnation material and chemical structure of the varnish. After varnishing process, net filing the pores completely will cause a difference between vertical and horizontal measurement and this will have different effects on people based on the angle from which they see it (Yalınkılıç, 1993; ASTM D 3023, 1988).

\section{Color}

To understand the changes in colour tint, we utilize the (Ho) angle. Between (a) red and (b) yellow, Ho angle is a sign that shows the way the colour changes (ASTM 3359, 1976; ASTM 661, 1993).

\section{Adherence}

Adaptation of the varnish layer to tree's limited working 
Table 12. Various variance analyze on chestnut and scoth pine.

\begin{tabular}{lccccc}
\hline VB & CT & SD & FD & Fh & ID \\
\hline Scoth pine & & & & & \\
Chemicals treatment & 1.88 & 7 & 0.268 & 1.163 & 0.3443 \\
Season-month & 121.66 & 6 & 20.27 & 87.66 & $0.0000^{*}$ \\
Estimate ratio & 9.714 & 42 & 0.2313 & - & - \\
Total & 133.25 & 55 & - & - & - \\
& & & & & \\
Chestnut & & & & & \\
Chemicals treatment & 0.9231 & 7 & 0.13 & 1.301 & 0.3802 \\
Season-month & 116.56 & 6 & 19.428 & 162.21 & $0.0000^{*}$ \\
Estimate ratio & 5.030 & 42 & 0.1197 & - & - \\
& & & & & \\
Duncan testing of both types wood specify & & & & \\
Wood specify & 0.14501 & 1 & 0.1450 & 0.878 & 0.3611 \\
Chemicals treatment & 237.07 & 6 & 39.51 & 239.18 & $0.0000^{*}$ \\
Season-month & 1.720 & 7 & 0.245 & 1.488 & 0.1805 \\
Estimate ratio & 16.024 & 97 & 0.16519 & - & - \\
Total & 254.96 & 111 & - & - & - \\
\hline
\end{tabular}

VR, variance base; CT, checked total; SD, freedom degree; ID, importance degree.

Table 13. Various variance analyze (testing of duncan) on loss of weight.

\begin{tabular}{|c|c|c|c|c|c|c|c|c|c|}
\hline \multirow{2}{*}{$\begin{array}{l}\text { Seasons/ } \\
\text { Months }\end{array}$} & \multicolumn{2}{|c|}{ Scoth pine } & \multicolumn{2}{|c|}{ Chestnut } & \multirow{2}{*}{$\begin{array}{l}\text { Chemicals } \\
\text { Material }\end{array}$} & \multicolumn{2}{|c|}{ Scoth pine } & \multicolumn{2}{|c|}{ Chestnut } \\
\hline & AV & $\mathrm{Hg}$ & AV & $\mathrm{Hg}$ & & AV & $\mathrm{Hg}$ & AV & $\mathrm{Hg}$ \\
\hline IM & 0.56 & $b c$ & 0.41 & $a b$ & 1-Naturel & 2.94 & $a$ & 2.35 & $a$ \\
\hline II M. & 0.65 & $a b c$ & 0.61 & $a b$ & 2-S.V. & 0.25 & b & 0.21 & b \\
\hline III M & 0.54 & $\mathrm{bc}$ & 0.39 & $\mathrm{~b}$ & 3-P.V. & 0.22 & b & 0.26 & b \\
\hline IV M & 0.90 & $\mathrm{a}$ & 0.66 & $\mathrm{a}$ & 4-WR+S.V. & 0.23 & b & 0.20 & b \\
\hline 3 Month & 0.54 & $\mathrm{bc}$ & 0.41 & $a b$ & 5-WR+P.V. & 0.23 & $b$ & 0.20 & b \\
\hline 6 Month & 0.77 & $a b$ & 0.56 & $a b$ & 6-Tan+SV & 0.18 & b & 0.20 & $b$ \\
\hline 9 Month & 0.39 & $c$ & 0.53 & $a b$ & 7-Tan+.PV. & 0.11 & $b$ & 0.15 & b \\
\hline 12 Month & 0.42 & c & 0.50 & $a b$ & - & - & - & - & - \\
\hline
\end{tabular}

$\mathrm{S}$, Seasons; M, months; SV, synthetic varnish; PV, polyurethane varnish.

Table 14. Various variance analyze on chestnut and scoth pine.

\begin{tabular}{lccccc}
\hline VB & CT & SD & FD & Fh & ID \\
\hline Scoth pine & & & & & \\
Chemicals treatment & 1.455 & 7 & 0.2079 & 2.040 & 0.0722 \\
Season-month & 51.41 & 6 & 8.56 & 84.06 & $0.0000^{\star}$ \\
Estimate ratio & 4.2813 & 42 & 0.1019 & & \\
Total & 57.15 & 55 & & & \\
& & & & & \\
Chestnut & & & & & \\
Chemicals treatment & 0.49 & 7 & 0.071 & 1.635 & 0.1522 \\
Season-month & 31.53 & 6 & 5.25 & 120.74 & $0.0000^{\star}$ \\
Estimate ratio & 1.82 & 42 & 0.043 & & \\
Total & 33.85 & 55 & & & \\
\hline
\end{tabular}


Table 14. Contd.

\begin{tabular}{lccccc}
\hline Duncan testing of both types wood specify & & & & \\
Wood specify & 0.3822 & 1 & 0.38 & 0.65 & 0.4280 \\
Chemicals treatment & 31.23 & 6 & 5.20 & 8.95 & $0.0000^{*}$ \\
Season-month & 1.78 & 7 & 0.25 & 0.44 & 0.8747 \\
Estimate ratio & 56.36 & 97 & 0.5810 & & \\
Total & 89.767 & 111 & & & \\
\hline
\end{tabular}

VR, variance base; CT, checked total; SD, freedom degree; ID, importance degree.

space depends mostly on elasticity (Özen and Sönmez, 1996; Feist, 1990; Özen and Gözeneli 1992). If there is no refraction in cutting place or varnish sawdust is cut like thin fibres, it shows that cohesion power of the varnish is high while its elasticity is normal .It is a very important parameter. That the least layers of weight took place in the impregnated and varnished samples demonstrated that the proceedings have been concluded with the best results.

Budakçı et al (2010) acrylic and polyurethane varnishes have been used in various types of wood, while the other needle-leafed woods with low bonding strength had positive results. In addition, there is the study of the bonding strength between layers of varnish wood-filler adhesion failure to intersect, where the maximum filling of solid layers of varnish on the last layer formed on the bonding strength was found to be ineffective. Sönmez and Budakçı (1998) reported the value of the highest bonding strength, in which varnish has been achieved three times in its implementation. Varnish cohesion between molecules on the surface with lower bond adhesion strength had an impact on postagestamp values, based on the report of the effect of reduction. Söğütlü and Sönmez (2006) gave example of changing the tint of the color as desired, and selected coffee decorative applications, two-component varnishes colored with chemical paint beech wood material coated with little or no change in color (Söğütlü and Sonmez, 2006). Sönmez and Budakçı (1999) decrease the brightness of vessel fully filled cavities in the wood, in different directions from the surface to reflect light and reduce the severity of the described.

Decker et al. (2004) gave $30 \mathrm{~mm}$ thick coated, waterbased UV-curing. At the end of the accelerated aging with the brightness of the hardness of PU-acrylate lacquer taurine being determined, the mechanism of decomposition of urethane $(\mathrm{C}-\mathrm{NH})$ maximum linkages shows that sensitivity has been reported.

\section{Conclusion}

According to the results, the highest retention in Scotch pine wood occurred in water repellent + polyurethane varnish $\left(82.02 \mathrm{~kg} / \mathrm{m}^{3}\right)$ and in chestnut tree wood, it occurred in water repellent + polyurethane varnish $(9.80$ $\left.\mathrm{kg} / \mathrm{m}^{3}\right)$. The highest brightness level is measured in the 9th month (52.56\%) for Scotch pine and in the 12th month $(67.94 \%)$ for chestnut pine. The highest percentage of colour change is measured in season IV $(67.07 \%)$ for Scotch pine and also in season IV $(55.95 \%)$ for chestnuts tree. The highest percentage of adherence resistance is measured in the 9th month $(3.83 \%)$ for Scotch pine and in the 3,6 and 9th months (3.66\%) for chestnut. The highest rate of weight loss is measured as $0.99 \mathrm{~g}$ in Scotch pine while it is $0.66 \mathrm{~g}$ in chestnut tree.

\section{REFERENCES}

Altınok M (1987). Mobilya üretiminde endüstriyel tasarım ,Gazi Üniv. Fen . Bil. Enst. Yük.Lis.Tezi, Ankara.

ASTM 1413 (1988). Standart Method of Testing Wood Preservatives by Laboratory Soilblock, ASTM, U.S.A.

ASTM 2244 (1990). Exterior Discoloration Of Varnıshes ;ASTM USA.

ASTM 3359 (1976). Measuring Adhesion By Tape Test ASTM.

ASTM 358 (1978). Wood to Be Used as Panels in Weathering Test of Coatings, ASTM, USA.

ASTM 4366 (1980). Hardness of organics coatings by pendilium damping test ASTM,USA.

ASTM 661 (1993). Standard Test Method For Of Crackking Of Exterior Paints, ASTM, U.S.A.

ASTM D 3023 (1988). Determination of resistance of factory applied coatings on wood products of stain and reagents, ASTM USA.

Baysal E (1994). Çeşitli Borlu ve WR Bileşiklerin Kızılçam Odununun Bazı Fiziksel Özelliklerine Etkisi, Yüksek Lisans Tezi, K.T.Ü. Fen Bilimleri Enstitüsü, Trabzon.

Boxall J, Hayes GF (1984). The Performance of Extender - Modıfied Clear Finishes on Exterior Timber. J. Princes Risborough Laboratory.

Bozkurt Y, Göker Y (1986). Orman Ürünlerinden Faydalanma, İstanbul Üniversitesi Orman Fakültesi Dergisi, Yayın No:3402/379.

Bozkurt Y, Göker Y, Erdin N (1993). Emprenye Tekniği, İstanbul Üniversitesi, I. Baskı, Yayın No:3879, Orman Fakültesi Yayın No:4135, İstanbul.

Budakçı M, Sönmez A (2010). Bazı Ahşap Verniklerin Farklı Ağaç Malzeme Yüzeylerindeki Yapışma Direncinin Belirlenmesi, J. Fac. Eng. Arch. Gazi Univ. Cilt 25(1):111-118.

Decker C, Masson F, Schwalm R (2004). Weathering Resistance of Waterbased UV-Cured Polyurethane-Acrylate coatings, Polym. Degrad. Stab. 83:309-320.

Feist WC (1988). Outdoor Wood Weathering and Protection, Advances in Chemistry Series, Am. Chem. Soc. 11:25-28.

Feist WC (1990). Weathering Performance of Finishing Wood Pretreated Wish Water Repellent Preservatives. For. Prod. J. 40:2126.

Garlack NB, Sward GB (1972). Weathering Tests. Painting Testing Manual 7:371-372.

Grantham JB, Black JM (1976). Naturel Exterior Finishes for Wood in The Pacific Nortwest. For. Prod. J. 26:8-16.

Özen R, Gözeneli H (1992). Türkiye' de Üretilen Parke Cilalarının Çeşitli Ağaç Türlerinde Aşınma ve Sertlik Özelliklerine Yaptığı Etkiler, 
Ormancılık Kongresi, Ekim 1992, Trabzon Bildiriler Kitabı, Cilt 2:1120.

Özen R, Sönmez A (1996). Ahşap Verniklerinin Harici Etkilere Karşı Dayanıklılıkları, DPT Projesi, Proje Kesin Sonuç Raporu, Proje Kodu:96202.

Richardson BA (1978). Wood Preservation, The Construction Press, Lancaster.

Rowell RM, Feist WC, Ellis WD (1981). Weathering Of Chemically Modified Southren Pine. Wood Sci. 13:202-208.

Söğütlü C, Sönmez A (2006). Değişik Koruyucular ile İşlem Görmüş Bazı Yerli Ağaçlarda UV Işınlarının Renk Değiştirici Etkisi, Gazi Üniversitesi Müh. Mimarlık Fak. Dergisi 21(1):151-159.

Sönmez A (1989). Ağaçtan Yapılmış Mobilya Üstyüzeylerinde Kullanılan Verniklerin Önemli Mekanik, Fiziksel ve Kimyasal Etkilere Karşı Dayanıklılıkları, Doktora Tezi, G.Ü. Fen Bilimleri Enstitüsü, Ankara.

Sönmez A, Budakçı M (1998). Vernik Katman Kalınlıgının Yüzeye Yapımsa Direncine Etkisi, Politeknik Dergisi, Cilt:1, Sayı:3-4, S:1-6.
Sönmez, A., Budakçı, M. (1999) Vernik Katman Kalınlıgının Parlaklıga Etkisi, Politeknik Dergisi, Cilt:12, Sayı:3, S:747-757.

TS 4755 (1986). Mobilya Yüzeyleri - Aşınma Mukavemetinin Tayini , T.S.E. , Ankara, I. Baskı, Mart.

TS 6884 (1989). Ahşap Mobilya Yüzeyleri Vernikli ve Boya Katmanlarının Yapışma Mukavemetinin Tayini, T.S.E., Ankara, Mart.

Var AA (1994). Doğal Reçine Kullanımının Ağaç Malzemenin Su İtici Özellikleri Üzerine Etkisi, Yüksek Lisans Tezi, K.T.Ü. Fen Bilimleri Enstitüsü, Trabzon.

Williams R, Feist WC (1991). Weathering Durability of Cronium Treated Sothern Pine. For. Prod. J. 41:8-14.

Williams R, Feist WC (1993). Durability of Paint or Solıd Color Stain Applied to Preweatherd Wood. For. Prod. J. 43:1-5.

Yalınkılıç MK (1993). Ağaç Malzemenin Yanma, Higroskopisite ve Boyutsal Stabilite Özelliklerinde Çeşitli Emprenye Maddelerinin Neden Olduğu Değişiklikler ve Bu Maddelerin Odundan Yıkanabilirlikleri, K.T.Ü. Orman Fakültesi Orm.End. Müh. Böl., Doçentlik Tezi, Trabzon. 